\title{
Endobronchial Ultrasound-Guided Transbronchial Needle Aspiration in the Diagnosis of Hilar and Mediastinal Lymph Node Metastases of Melanoma
}

\author{
José-Fernando VAL-BERNAL' ${ }^{\text {iD }}$, María MARTINO² ${ }^{\text {iD, Elena YLLERA }}{ }^{3}$, Félix ROMAY4, \\ María SÁNCHEZ-ARES 5 , Ihab Abdulkader NALLIB ${ }^{5}$ \\ 'Pathology Unit, Medical and Surgical Sciences Department, University of Cantabria and IDIVAL Research Institute, SANTANDER, SPAIN \\ ${ }^{2}$ Anatomical Pathology Service, Marqués de Valdecilla University Hospital, University of Cantabria and IDIVAL Research Institute, SANTANDER, SPAIN \\ ${ }^{3}$ Radiodiagnostic Service and ${ }^{4}$ Neumology Service, Marqués de Valdecilla University Hospital, SANTANDER, SPAIN \\ ${ }^{5}$ Anatomical Pathology Service, University Hospital, Santiago de Compostela, SPAIN
}

\begin{abstract}
Objective: Endobronchial ultrasound-guided transbronchial needle aspiration (EBUS-TBNA) is a minimally invasive technique for investigating hilar and mediastinal lymphadenopathy. This study reports eleven cases in which EBUS-TBNA was used to assess mediastinal and hilar lymph nodes for the presence of metastatic melanoma.
\end{abstract}

Material and Method: A retrospective study was performed of all patients who had a history of melanoma and underwent EBUS-TBNA to assess hilar or mediastinal lymphadenopathy for the presence of metastatic melanoma. In seven cases, molecular analysis to detect mutations in the BRAF gene was also used.

Results: Eight patients had been diagnosed with malignant melanoma in the past (mean 54.4 months, range 18 to 115 months) while in the other three this tumor was primarily diagnosed in the staging phase. The male-female ratio was 6:5, and the mean age was 60.3 years (range 42 to 88 years). The mean hilar or mediastinal lymph node size detected with computed tomography was $3.0 \mathrm{~cm}$ (range $1.1 \mathrm{to} 8.1 \mathrm{~cm})$. Eight (72.7\%) cases had metastases to the lung associated with metastases in the mediastinal lymph nodes. In four (50\%) of these cases, the lung metastasis was solitary. Three (27.3\%) cases had metastases in the mediastinal lymph nodes in absence of lung metastases. Metastatic melanoma was diagnosed by cytology and confirmed by cell block study with immunohistochemistry in all cases. BRAF mutations were detected in two (28.6\%) of seven cases studied.

Conclusion: Cytology and tissue samples obtained from EBUS-TBNA are adequate to detect metastatic melanoma and permit in some cases the determination of biomarkers and identify the presence or absence of mutations in the BRAF gene. The procedure is safe, fast, and precise for the staging of melanoma.

Key Words: Melanoma, Metastasis, Bronchoscopy, Cytology, Immunohistochemistry

\section{INTRODUCTION}

Primary malignant melanoma (MM) is a tumor that most often originates in the skin but can appear in multiple sites where melanocytes are present. This tumor accounts for $5.2 \%$ of all cancers and is now regarded as the fifth most common cancer in men and the sixth most common cancer in women in the western world (1). In addition, the incidence of this tumor is increasing in white populations worldwide. The median age at diagnosis is 57 years (2).

MM has a high malignant potentiality. Metastatic spread may arise from small tumors (3). MM is known to disseminate virtually to all the organs. However, initial spread occurs to regional lymph nodes with subsequent extension to deep

(Turk Patoloji Derg 2019, 35:92-101)

Received : 28.05.2018 Accepted : 16.07.2018 nodes including mediastinal nodes. Therefore, intrathoracic lymph node metastases are frequent. Thus, Das Gupta and Brasfield (4) found metastatic MM in mediastinal nodes in 69 (55\%) out of 125 patients studied at autopsy.

The most important factor for successful management of $\mathrm{MM}$ is early diagnosis. Patients with metastatic melanoma have limited treatment opportunities. In cases of localized metastasis, surgical resection can enable in some patients a prolonged interval of recurrence-free survival.

Precise pathological diagnosis of mediastinal lymphadenopathy in cases of MM is crucial for effective treatment. Open thoracic surgery and mediastinoscopy are standard methods for hilar and mediastinal lymph node staging.

Correspondence: José-Fernando VAL-BERNAL

Pathology Unit, Medical and Surgical Sciences Department,

University of Cantabria, SANTANDER, SPAIN

E-mail: fernando.val@unican.es Phone: +34 942315098 
However, they are costly, invasive, require general anesthesia, and can lead to complications. Endobronchial ultrasound-guided transbronchial needle aspiration (EBUS-TBNA) cytology is a minimally invasive, safe and suitable procedure that can be used for diagnosing hilar and mediastinal lymphadenopathy. However, there is limited experience with this procedure. Thus, there is a case report (5) and a series of nine cases (seven metastatic) (6) in the literature using this technique to detect metastatic MM to the mediastinal lymph nodes.

In this study, we investigated the feasibility of EBUS-TBNA for evaluating hilar and mediastinal lymphadenopathy in MM. Hilar and/or mediastinal lymphadenopathy presented as a recurrence or a primary diagnosis in a series of eleven patients diagnosed with MM.

\section{MATERIAL and METHOD}

The methods used are similar to those performed in a previous EBUS-TBNA study in clear cell renal cell carcinoma (7). Between January 2011 and March 2018, we performed 1,500 EBUS-TBNA studies of hilar or mediastinal lymph nodes for a variety of clinical indications including malignancy. All the cases were identified inhouse. The lymph nodes sampled were enlarged (short axis $>1 \mathrm{~cm}$ ) according to computed tomography (CT) scans, and they were associated in some cases with nodular lesions in the lung.

Tumor staging was established according to the 7th edition of the AJCC Cancer Staging Manual (8).

EBUS-TBNA was performed under local anesthesia and midazolam and fentanyl sedation as an outpatient procedure, using a flexible bronchoscope Olympus BFUC160F-OL8 (Olympus, Tokyo, Japan) and an ultrasound image processor Olympus EUS Exera EU-c60 (Olympus, Tokio, Japan). Specimens were obtained with a 22 -gauge needle. The average number of needle passes from each location was 3 (range 1-6).

An on-site evaluation was performed in all the cases and the specimen was assumed adequate. Each case had aspirate smears that were stained with Diff-Quick and Papanicolaou method. In all the cases we had cell block preparations. Sections of the cytoblocks were stained with hematoxylin and eosin. Considering the tissue limitation, we did not use the Fontana-Masson silver method for melanin. This pigment was evaluated in the sections stained with hematoxylin and eosin. Immunohistochemical study was carried out on formalin-fixed 4 - $\mu$ m-thick paraffin-embedded tissue sections using the EnVision FLEX Visualization System (Dako, Agilent Technologies, SL, Las Rozas, Madrid, Spain). Antibodies used in the immunohistochemical study are detailed in Table I. The immunohistochemical reactions were performed using appropriate tissue controls. Automatic staining was performed on a Dako Omnis autostainer (Agilent Technologies, SL).

PDL1 immunohistochemistry and BRAF mutation analysis were performed in four and seven cases respectively. In the remaining cases, there was not enough material in the cytoblock. PDL1 protein expression was carried out on paraffin-embedded tissue cut into $3 \mu \mathrm{m}$ sections using two different antibody clones, Dako 28-8 and Dako 22C3. Formalin-fixed, paraffin-embedded agar cell pellets prepared from the PD-L1-positive and PD-L1-negative cell line and tonsil tissues were used as controls. Assessment of PD-L1 staining was performed by a pathologist previously trained on the 28-8 and 22C3 Dako pharmDx assays. The percentage of tumor cells with linear membranous staining

Table I: Immunohistochemical antibodies used in this study

\begin{tabular}{|c|c|c|c|c|}
\hline Antibody & Source & Clone & Dilution & Retrieval solution pH (Dako) \\
\hline Human melanosome & Dako & HMB45 & FLEX RTU & High \\
\hline Melan A & Dako & A103 & FLEX RTU & High \\
\hline S100 protein & Dako & Polyclonal & FLEX RTU & High \\
\hline SOX10 & Biocare Medical & BC34 & $1: 100$ & High \\
\hline Cytokeratin & Dako & AE1/AE3 & FLEX RTU & High \\
\hline Cytokeratin 7 & Dako & OV-TL $12 / 30$ & FLEX RTU & High \\
\hline CD56 & Dako & $123 \mathrm{C} 3$ & FLEX RTU & High \\
\hline Synaptophysin & Dako & DAK-SYNAP & FLEX RTU & High \\
\hline p40 & Biocare Medical & $\mathrm{BC} 28$ & $1: 50$ & High \\
\hline CD45 & Dako & $2 \mathrm{~B} 11+\mathrm{PD} 7 / 26$ & FLEX RTU & Low \\
\hline TTF-1 & Dako & 8G7G3 & FLEX RTU & High \\
\hline
\end{tabular}

Biocare Medical, Pacheco, CA, USA; Dako (Agilent Technologies, SL, Las Rozas, Madrid, Spain); RTU, Ready-to-Use 
at any intensity was reported following 28-8 and 22C3 Dako pharmDx assays interpretation guides.

In seven cases, DNA extraction was carried out to study BRAF mutation analysis. After hematoxylin-eosin-stained slide review and tumor tissue selection, genomic DNA was extracted from 5 to 10 ( 5 - $\mu$ m-thick) sequential tissue sections for each specimen using the QIAGEN Deparaffinization Solution and the QIAamp DNA FFPE Tissue Kit (Qiagen, Germany) according to manufacturer's guidelines. The concentrations were evaluated by spectrophotometry (NanoDrop 1000 Spectrophotometers, Thermo Scientific Inc., MA, USA). Pyrosequencing of BRAF mutation regions (codon 464-469 and codon 600) was performed with the Therascreen BRAF Pyro Kit (Qiagen, Germany) on a PyroMark Q24 System (Qiagen, Germany) according to the manufacturer's handbook.

Because of limited material and variation of the staining panel over the years, not all tumors were stained with the same series of antibodies.

This study was approved by the Ethics Committee of IDIVAL Research Institute (CI: 2018.053) and confirmed to the provisions of the Declaration of Helsinki.

\section{RESULTS}

Over the seven-year and four-month study period, we analyzed the data from eleven patients who underwent EBUS-TBNA with cytoblock. The patients underwent this procedure because of suspected hilar or mediastinal metastasis according to CT. Eight patients had been diagnosed with MM in the past (mean 54.4 months, range 18 to 115 months) while in three this tumor was primarily diagnosed in the staging phase by means of EBUS-TBNA (Table II). There were 6 male and 5 female patients (M:F, 6:5) and the mean age was 60.3 years (range 42 to 88 years).

CT scans with contrast enhancement in the eight patients showed well-defined, large, heterogeneously-enhancing solid masses in the hilar zone or anterior mediastinum (Figure 1A-C). The mean hilar or mediastinal lymph node size detected with CT was $3.0 \mathrm{~cm}$ (range 1.1 to $8.1 \mathrm{~cm}$ ). Eight $(72.7 \%)$ cases had metastases to the lung associated with metastases in the mediastinal lymph nodes; and in four $(50 \%)$ of these cases, the lung metastasis was solitary. Three $(27.3 \%)$ cases had metastases in the mediastinal lymph nodes in absence of lung metastases (Table II). Endobronchial ultrasound study of the lymph nodes included increased size, irregularity, non-homogeneity, hypervascularization and increased eco-quality (Figure 1D).
Cytological smears revealed a lymphoid and hematic background on which there were atypical cells arranged in small clusters (37.5\%) or scattered as discohesive groups or isolated elements (62.5\%). Cellularity was moderate (27.3\%) to high (72.7\%). The cytological type varied between epithelioid (54.5\%), spindle cell (27.3\%) and epithelioid and spindle cell (18.2\%). Epithelioid or round cells formed groups of large, disaggregated, atypical cells or isolated elements occasionally binucleated, or multinucleated. The nuclei were frequently in an eccentric position (Figure 2). These nuclei usually had a regular outline, and the nuclear chromatin was evenly distributed. Nucleoli were prominent. Nuclear pseudoinclusions (intranuclear cytoplasmic invaginations) were seen in isolated cells in most cases (Figure 3A). Presence of macronuclei was noticed. Multiple small cytoplasmic vacuoles were observed in smears stained with Diff-Quick (Figure 3B). Singly atypical dispersed cells showed melanin pigment in five $(45.4 \%)$ of cases (Figure 3C). Smears containing a mixture of epithelial-type and spindle cells or only spindle cells usually formed cohesive clusters.

All cases were categorized as positive for metastatic melanoma.

The cell blocks showed groups or masses of round to oval tumor cells with moderate amount of cytoplasm and moderately pleomorphic nuclei with coarse chromatin (Figure 4A). Nucleoli were prominent. Three main cytologic types were recognized: epithelioid (54.5\%) (Figure 4B), spindle cell (27.3\%) (Figure 4C) and mixed epithelioid and spindle cells (18.2\%). Multinucleated cells were prominent in one case (Figure 4D). Melanin pigment was present in some cells in seven (63.6\%) cases. Immunohistochemistry revealed positive reactivity for HMB45 (8/11, 72.7\%) (Figure 5A), Melan A (9/11, 81.8\%) (Figure 5B), SOX10 (10/11, 90.9\%) (Figure 5C), and S100 protein (10/11, 90.9\%) (Figure 5D) in tumor cells (Table II). Cytokeratin (CK) AE1/AE3 (0/6, 0\%), CK7 (0/2, 0\%), CD 56 (0/2, $0 \%)$, synaptophysin $(0 / 2,0 \%), \mathrm{p} 40(0 / 2,0 \%)$ leukocyte common antigen (CD45, 0/2, 0\%) and TTF1 (0/8, 0\%) were no reactive. In the immunohistochemical study of the melanoma markers (HMB45, Melan A, SOX10, S100 protein) it was observed that four markers were positive in $7(63.6 \%)$ cases, three markers in $1(9.1 \%)$ case, and two markers in $3(27.3 \%)$ cases.

The histological study of the cytoblocks plus immunohistochemistry was considered confirmatory of the diagnosis. 

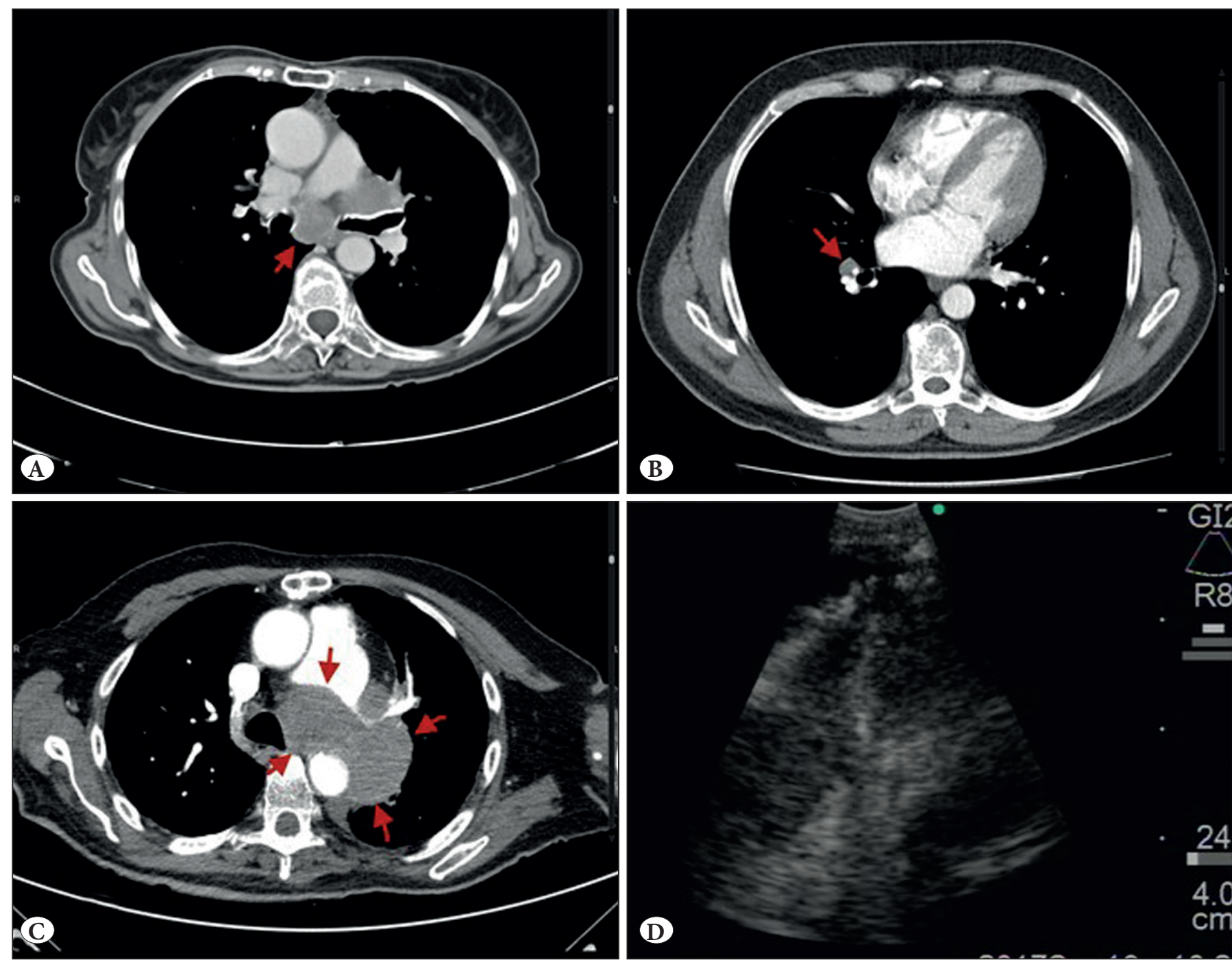

Figure 1: Axial thoracic CT scans and endobronchial ultrasound. A) CT scan (Case 1). The red arrow shows a rounded pathological lymph node with low attenuation values located in the subcarinal region (level 7). B) CT scan (case 5). The arrow indicates a rounded, homogeneous hypodense nodular image at level 10R, corresponding to a pathological lymph node by size and location. C) CT scan (case 8) The arrows indicate a large, hypodense heterogeneous lymphadenopathic conglomerate. It has been located in the left paratracheal region $(4 \mathrm{~L})$ that extends to the aortopulmonary window and the ipsilateral hilum. It produces the stenosis of the left main pulmonary and contacts more than $50 \%$ of the aortic circumference. D) Endobronchial ultrasound (case 8). A needle is observed within a large, heterogeneous lymph node conglomerate in the left paratracheal region.

PDL1 biomarker was negative for all cases. The study of the BRAF mutations showed positivity in two (28.6\%) of seven cases studied (Table II). Mutations were detected in exon 15 , codon 600 of the BRAF gene.

In this study, there were no inadequate cytological samples. No clinical complications were observed in patients due to the use of the procedure.

\section{DISCUSSION}

$\mathrm{MM}$ is an aggressive neoplasm that can metastasize to all organs of the human body and its manifestations are multifaceted. The metastatic pattern was analyzed by autopsy of 216 patients by Patel et al (9). The most common organs involved were the lymph nodes $(73.6 \%)$, lungs (71.3\%), liver (58.3\%), brain (49.1\%), bone (48.6\%), heart (47.2\%), adrenal glands (46.8\%), and gastrointestinal tract (43.5\%). Single organ metastases were very uncommon in cutaneous MM. On the other hand, Webb in a radiologic and pathologic study of 65 patients with intrathoracic metastases from MM observed that 35 (54\%) out of them had hilar or mediastinal lymph node metastases. In $80 \%$ of the cases, these lymph nodes were enlarged (10). 
Table II: Clinical details of patients with mediastinal metastases caused by melanoma

\begin{tabular}{|c|c|c|c|c|c|c|c|c|c|}
\hline $\begin{array}{l}\text { Case } \\
\text { no }\end{array}$ & $\begin{array}{c}\text { Age at } \\
\text { metastases } \\
(y) / \text { Sex }\end{array}$ & $\begin{array}{l}\text { Site of } \\
\text { primary }\end{array}$ & $\begin{array}{l}\text { Thoracic } \\
\text { imaging }\end{array}$ & $\begin{array}{l}\text { Mediastinal } \\
\text { lymph node } \\
\text { short axis } \\
\text { maximum } \\
\text { diameter }(\mathrm{cm})\end{array}$ & $\begin{array}{l}\text { Immunohis- } \\
\text { tochemistry } \\
\text { on the cell } \\
\text { block }\end{array}$ & $\begin{array}{c}\text { BRAF } \\
\text { (V600E) } \\
\text { mutation }\end{array}$ & PDL-1 & $\begin{array}{l}\text { Previous } \\
\text { staging }\end{array}$ & $\begin{array}{c}\text { Interval to } \\
\text { metastasis } \\
\text { (months) }\end{array}$ \\
\hline 1 & $80 / \mathrm{F}$ & Left leg & $\begin{array}{l}\text { Mediastinal } \\
\text { nodes } \\
\text { Pulmonary } \\
\text { nodules }\end{array}$ & 2.6 & $\begin{array}{c}\text { HMB45+, } \\
\text { Melan A+, } \\
\text { SOX10+, S100 } \\
\text { protein+ }\end{array}$ & Negative & Negative & pT4pN0M0 & 71 \\
\hline 2 & $67 / \mathrm{M}$ & Nasopharynx & $\begin{array}{l}\text { Mediastinal } \\
\text { nodes } \\
\text { Absence of } \\
\text { pulmonary } \\
\text { nodules }\end{array}$ & 2.3 & $\begin{array}{l}\text { HMB45+, } \\
\text { MelanA+, } \\
\text { SOX10-, S100 } \\
\text { protein+ }\end{array}$ & - & - & pT3pN1M1 & 0 \\
\hline 4 & $43 / \mathrm{F}$ & Back & $\begin{array}{l}\text { Mediastinal } \\
\text { node } \\
\text { Pulmonary } \\
\text { nodule }\end{array}$ & 1.5 & $\begin{array}{c}\text { HMB45-, } \\
\text { Melan A-, } \\
\text { SOX10+, S100 } \\
\text { protein+ }\end{array}$ & Negative & Negative & pT4pN3M0 & 35 \\
\hline 5 & $55 / \mathrm{M}$ & Thorax & $\begin{array}{l}\text { Mediastinal } \\
\text { node } \\
\text { Pulmonary } \\
\text { nodule }\end{array}$ & 3.3 & $\begin{array}{c}\text { HMB45+, } \\
\text { Melan A+, } \\
\text { SOX10+, S100 } \\
\text { protein+ }\end{array}$ & - & - & pT3pN0M0 & 18 \\
\hline 6 & $63 / F$ & Left thigh & $\begin{array}{l}\text { Mediastinal } \\
\text { node } \\
\text { Pulmonary } \\
\text { nodule }\end{array}$ & 1.5 & $\begin{array}{c}\text { HMB45-, } \\
\text { Melan A-, } \\
\text { SOX10+, S100 } \\
\text { protein+ }\end{array}$ & Negative & Negative & pT3pN0M0 & 27 \\
\hline 9 & $54 / \mathrm{F}$ & Left shoulder & $\begin{array}{c}\text { Conglomerate } \\
\text { of mediastinal } \\
\text { nodes } \\
\text { Pulmonary } \\
\text { nodules }\end{array}$ & 4.0 & $\begin{array}{c}\text { HMB45+, } \\
\text { Melan A+, } \\
\text { SOX10+, S100 } \\
\text { protein+ }\end{array}$ & Positive & - & pT2pN0M0 & 38 \\
\hline 10 & $44 / \mathrm{M}$ & Lower back & $\begin{array}{l}\text { Mediastinal } \\
\text { nodes } \\
\text { Absence of } \\
\text { pulmonary } \\
\text { nodules }\end{array}$ & 4.0 & $\begin{array}{c}\text { HMB45+, } \\
\text { Melan A+, } \\
\text { SOX10+, S100 } \\
\text { protein+ }\end{array}$ & Positive & - & pT2pN0M0 & 40 \\
\hline 11 & $76 / \mathrm{M}$ & Unknown & $\begin{array}{l}\text { Pulmonary } \\
\text { nodule } \\
\text { Mediastinal } \\
\text { node } \\
\end{array}$ & 1.7 & $\begin{array}{c}\text { HMB45+, } \\
\text { Melan A+, } \\
\text { SOX10+, S100 } \\
\text { protein+ }\end{array}$ & Negative & - & T0pN1M1 & 0 \\
\hline
\end{tabular}




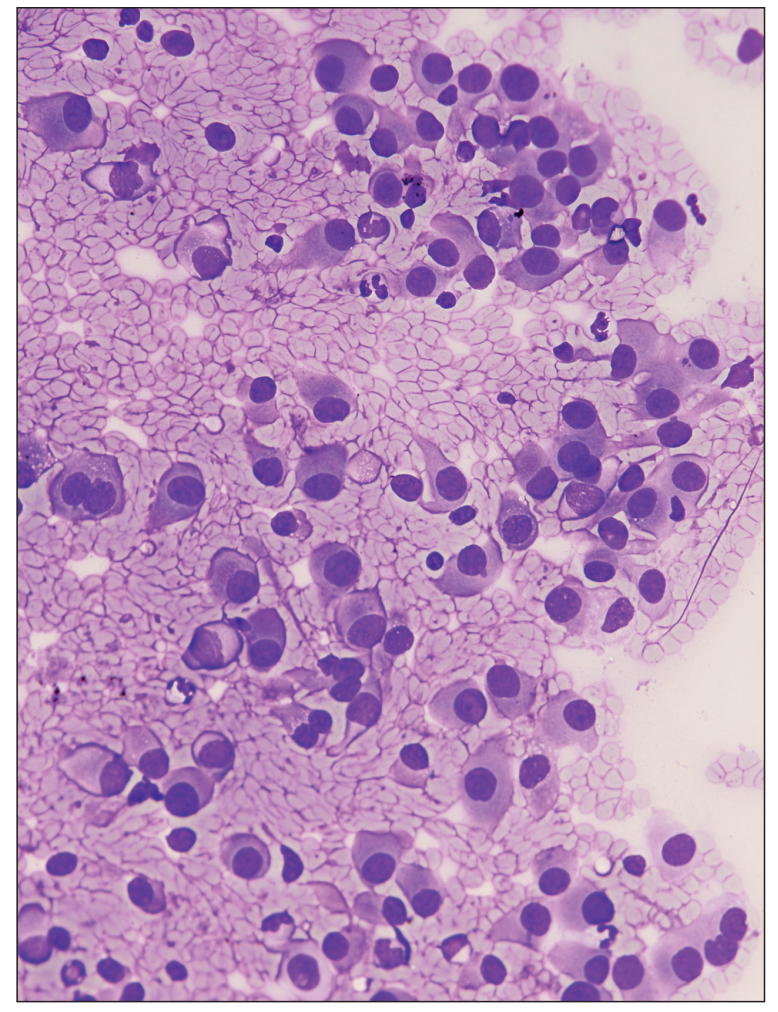

Figure 2: Cytological smear showing a hemorrhagic background on which there are epithelioid malignant cells with lack of cohesiveness. Eccentric nuclei are often seen. There is a binucleate tumor cell. Cytoplasmic melanin pigment is not apparent (case 5) (Diff-Quick stain; x400).

In patients with tumors arising below the diaphragm, the spread to intrathoracic nodes occurs via the thoracic duct, most likely by reflux of tumor cells. This duct, as a rule, drains lymph from the pelvis and abdomen. In cases with tumors arising above the diaphragm, the lymphatic spread to mediastinum nodes occurs by means of lymphatics connecting axillary, cervical, and mediastinal chains. In addition, in patients with metastatic pulmonary nodules (indicative of hematogenous spread to the lungs), secondary spread of tumor cells to hilar and mediastinal lymph nodes may occur (10).

The thorax should be the main focus for the screening of initial systemic MM dissemination (11). Mediastinoscopy with a sensitivity of $80 \%$ to $85 \%$ and a specificity of about $100 \%$ is considered the standard method for diagnosis of mediastinal lymphadenopathy with tissue confirmation. However, this method has limited access to nodal stations 2 and 4 (paratracheal), and 7 (subcarinal), and the access to hilar nodes can be difficult and may require thoracoscopy. In addition, mediastinoscopy is associated with a considerable rate of morbidity. Thus, this technique is associated with a neck scar and a $2 \%$ risk of morbidity and $0.08 \%$ of mortality.
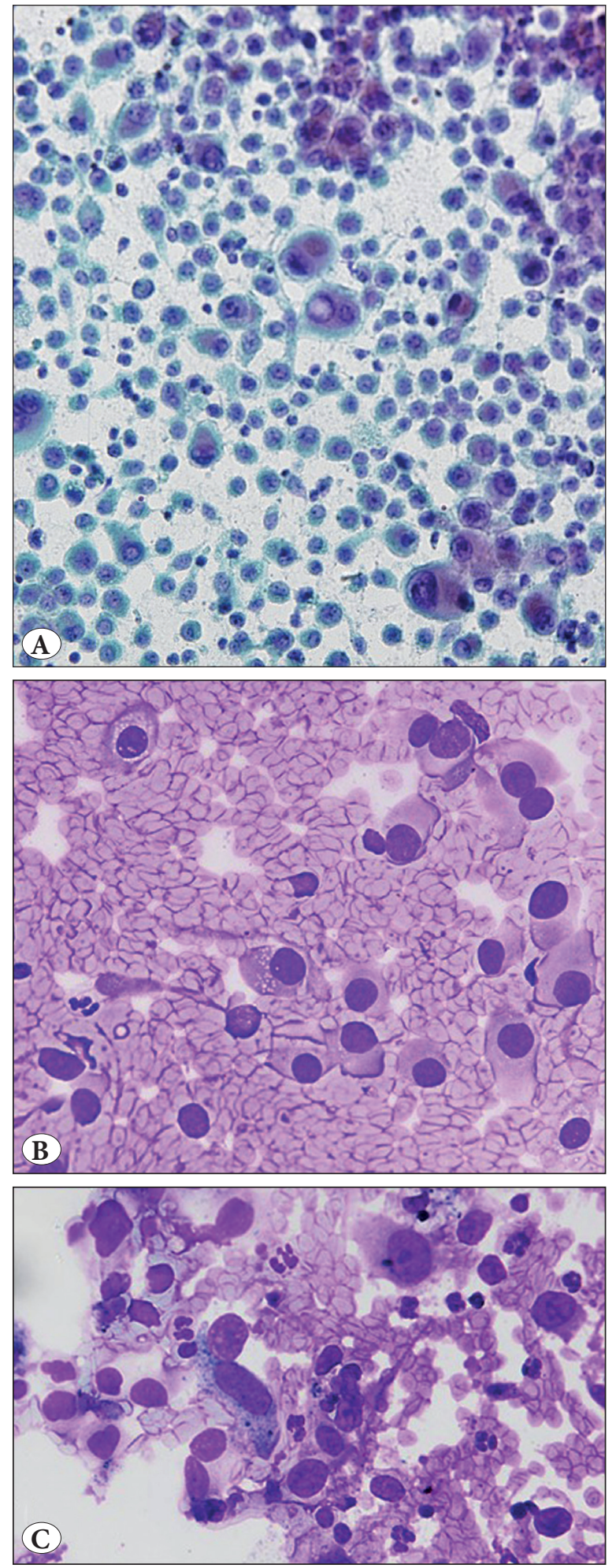

Figure 3: Cytological smear. A) A binucleate cell in the center of the image shows a pseudonuclear inclusion (intranuclear cytoplasmic invagination) (case 1) (Papanicolaou stain; x400). B) Two cells showing multiple small cytoplasmic vacuoles measuring $<1 \mu \mathrm{m}$ in diameter can be seen (case 3) (Diff-Quick stain; x400). C) Tumor cells with dusty melanin pigment stained in blue with Diff-Quick stain (case 2) (Diff-Quick stain; x400). 

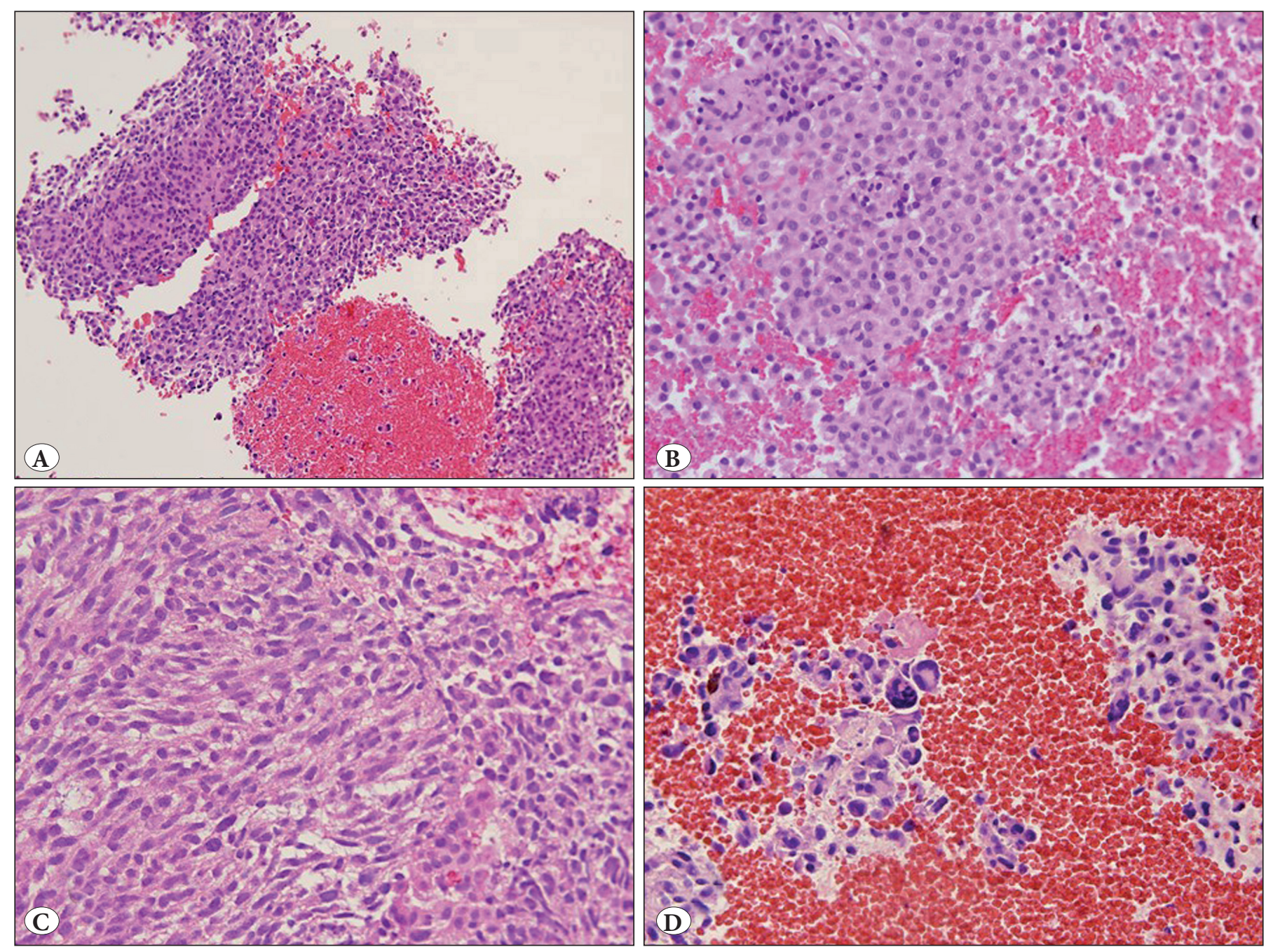

Figure 4: Routine hematoxylin-eosin stain of the cell blocks. A) Presence of tissue fragments of melanoma in a background of red cells (case 5) (H\&E; x200). B) Epithelioid cells (case 1) (H\&E; x400). C) Spindle cells (case 6) (H\&E; x400). D) Multinucleated giant cells (case 7) (H\&E; $\mathrm{x} 400)$.

Furthermore, the method cannot be repeatedly conducted on the same patient (12-14).

It is usually accepted that a normal lymph node has a maximum short-axis diameter of $10 \mathrm{~mm}$ or less (15). Metastasized lymph nodes tend to be larger than normal or benign lymph nodes. Computed tomography (CT) scan is usually used in the staging of metastatic melanoma and for control of high-risk patients after loco-regional surgical treatment. Thus, CT scanningisthemostreliableradiographic method for evaluating intrathoracic metastases including mediastinal and hilar lymphadenopathy $(16,17)$. However, CT scanning is insensitive to the presence of small nodal metastases and can show false-positive results evaluating large nodes (18). On the other hand, echofeatures alone are not reliable in determining the underlying etiology of hilar and mediastinal lymphadenopathy, including sarcoidosis, tuberculosis, lymphoma or metastatic recurrence (19). In addition, it should be taken into account that there is a wellknown association between non-Hodgkin lymphoma and melanoma (20). Furthermore, up to $20 \%$ of patients with melanoma may develop synchronously or metachronously other malignancies such as carcinomas, lymphomas, or sarcomas (21).

EBUS-TBNA has emerged as a minimally invasive, and highly precise technique for sampling intrathoracic lymph nodes. EBUS-TBNA combines endoscopic visualization with high-frequency ultrasound imaging which warrants obtain cytological and histological samples. Nevertheless, definitive and accurate cytologic diagnosis is challenging owing to the varied morphologic appearances of melanoma in cytologic preparations (21). However, the precise cytological diagnosis of metastatic melanoma starts with 

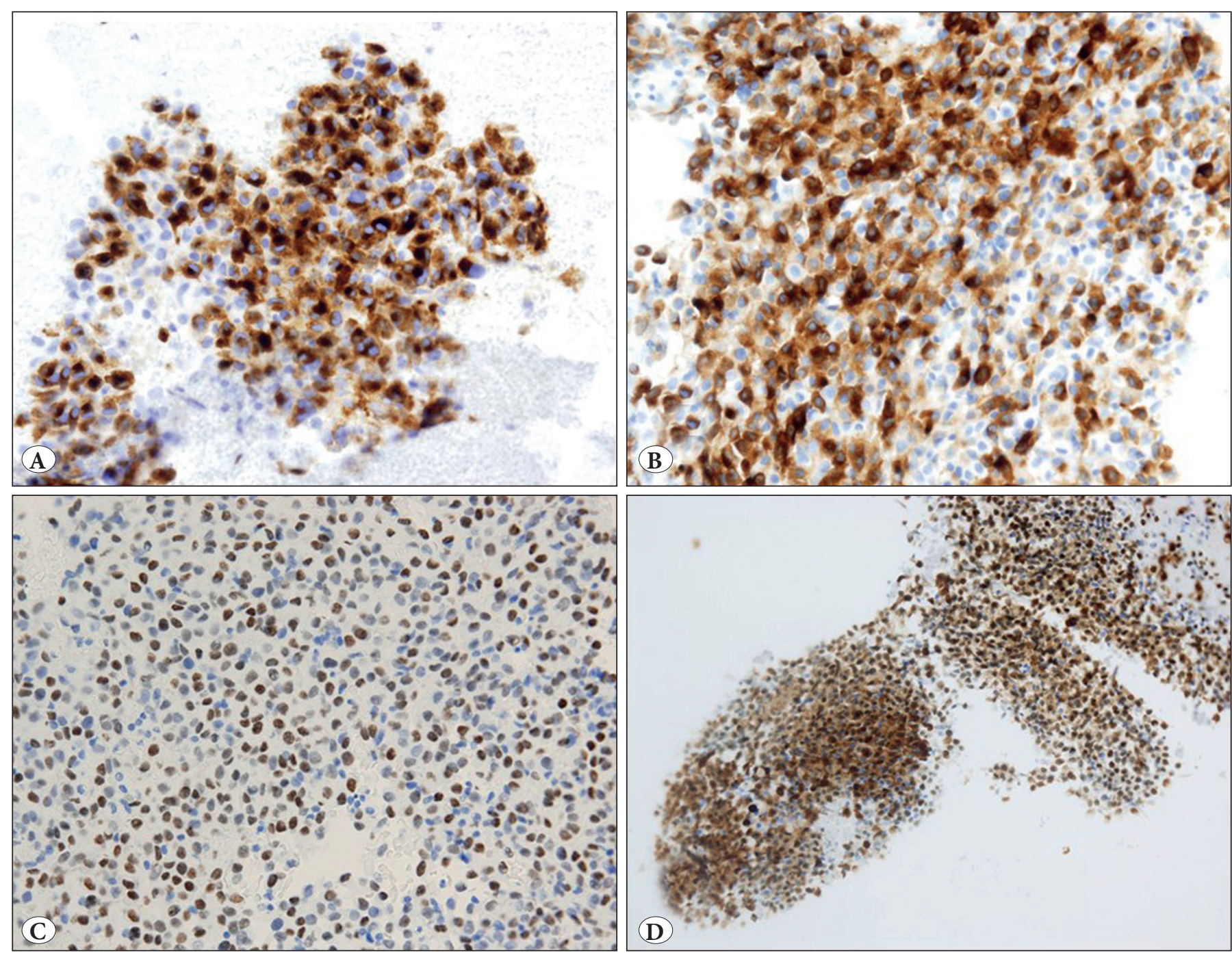

Figure 5: Immunohistochemistry. Neoplastic cells show reactivity for A) HMB45 (case 7) (IHC; x400). B) Melan A (case 5) (IHC; x400). C) SOX10 (case 5) (IHC; x400). D) S100 protein (case 5) (IHC; x200).

clinical history. Cytodiagnosis clues include poorly cohesive cells, blatant malignant features, epithelioid and spindled shapes, eccentric placement of nuclei, prominent nucleoli, nuclear pseudoinclusions, macronuclei, bi- or multinucleation, and small intracytoplasmic vacuoles. These small vacuoles measuring $<1 \mu \mathrm{m}$ in diameter are characteristic of melanoma cells (22). The melanin production, although diagnostic, is only observed in $\leq 50 \%$ of cases $(22,23)$. In this setting, melanin pigment can be difficult to distinguish from hemosiderin or anthracotic pigment. Melanin appears as fine dust-like intracytoplasmic pigment in atypical cells. Melanophages can also be distinguished. Fontana-Masson silver method can recognize the melanin pigment in difficult cases. From the practical point of view, the presence of tumor cells with dark pigment in a smear should include melanoma in the differential diagnosis.
The study of the cytoblock and the help of immunohistochemistry is especially useful in the evaluation of intrathoracic lymph nodes for suspected metastases. Immunohistochemical staining is crucial in differentiating metastatic melanoma from other tumors and imitators. Thus, a sensitivity of $94 \%$ to $95 \%$ and a specificity of $100 \%$ of the EBUS-TBNA method has been reported $(12,24)$. In this study, we observed immunohistochemical positivity at least for two melanoma markers. On the other hand, the procedure can provide sufficient tissue for biomarkers and molecular studies.

It is important to assess BRAF mutation status before treatment of metastatic melanoma. The frequency of BRAF mutation in primary melanoma ranges from 36 to $45 \%$, and $42-55 \%$ in metastatic melanoma (25). The presence of a BRAF mutation in early melanoma shows no association 
with disease-free interval or overall survival. However, the presence of a BRAF mutation in metastatic melanoma is associated with a poorer survival (25). Furthermore, the determination of the BRAF gene mutation allows the treatment with the appropriate BRAF kinase inhibitor vemurafenib (PLX4032) $(26,27)$.

The complication rate for EBUS-TBNA is low and varies from $1.23 \%$ (25) to $1.44 \%$ (26). They include device breakage, hemorrhage, pneumothorax, infections (mediastinitis, pneumonia, pericarditis, sepsis), and death (large cerebral infarction reported in one case) $(28,29)$.

In conclusion, EBUS-TBNA is an alternative minimally invasive technique for surgical mediastinal staging of MM. It can also be used to repeat procedures for additional required testing including biomarkers and molecular studies. The study of the cytoblock and the help of immunohistochemistry is especially useful in the evaluation of intrathoracic lymph nodes for suspected melanoma metastases. The procedure complications are very uncommon.

\section{CONFLICT OF INTEREST}

The authors declare no conflict of interest.

\section{FUNDING}

No external funding for this work.

\section{REFERENCES}

1. Siegel RL, Miller KD, Jemal A. Cancer Statistics, 2017. CA Cancer J Clin. 2017;66:7-30.

2. Rastrelli M, Tropea S, Rossi CR, Alaibac M. Melanoma: Epidemiology, risk factors, pathogenesis, diagnosis and classification. In Vivo. 2014;28:1005-12.

3. Mervic L. Time course and pattern of metastasis of cutaneous melanoma differ between men and women. PLoS One. 2012;7:e32955.

4. Das Gupta T, Brasfield R. Metastatic melanoma. A clinicopathological study. Cancer. 1964;17:1323-39.

5. Ryan DJ, McPhillips D, Bruzzi J, Breen D. A clue in a colour? EBUSTBNA in the analysis of isolated mediastinal lymphadenopathy. BMJ Case Rep. 2014;23:2014.

6. Jennings BR, Millward MJ, Amanuel B, Mulrennan S, Joosten SA, Phillips MJ. Role of endobronchial ultrasound in diagnosis and molecular assessment of metastatic melanoma. Respirology. 2012;17:991-6.

7. Val-Bernal JF, Martino M, Romay F, Yllera E. Endobronchial ultrasound-guided transbronchial needle aspiration in the diagnosis of mediastinal metastases of clear cell renal cell carcinoma. Pathol Res Pract. 2018;214:949-56.
8. Rubin P, Hansen JT. TNM staging atlas with oncoanatomy, 2nd ed. Philadelphia:Wolters Kluwer/Lippincott Williams and Wilkins, 2012;582-93.

9. Patel JK, Didolkar MS, Pickren JW, Moore RH. Metastatic pattern of malignant melanoma. A study of 216 autopsy cases. Am J Surg. 1978;135:807-10.

10. Webb WR. Hilar and mediastinal lymph node metastases in malignant melanoma. AJR Am J Roentgenol. 1979;133:805-10.

11. Gromet MA, Ominsky SH, Epstein WL, Blois MS. The thorax as the initial site for systemic relapse in malignant melanoma. Cancer. 1979;44:776-84.

12. Ye T, Hu H, Luo X, Chen $\mathrm{H}$. The role of endobronchial ultrasound guided transbronchial needle aspiration (EBUS-TBNA) for qualitative diagnosis of mediastinal and hilar lymphadenopathy: A prospective analysis. BMC Cancer. 2011;11:100.

13. Medford A, Bennett JA, Free CM, Agrawal S. Mediastinal staging procedures in lung cancer: EBUS, TBNA and mediastinoscopy. Curr Opin Pulm Med. 2009;15:334-42.

14. Ernst A, Anantham D, Eberhardt R, Krasnik M, Herth FJF. Diagnosis of mediastinal adenopathy-real-time endobronchial ultrasound guided needle aspiration versus mediastinoscopy. J Thorac Oncol. 2008;3:577-82.

15. Paño Brufau B, Sebastià Cerqueda C, Buñesch Villalva L, Salvador Izquierdo R, Mellado González B, Nicolau Molina C. Metastatic renal cell carcinoma: Radiologic findings and assessment of response to targeted antiangiogenic therapy by using multidetector CT. Radio Graphics. 2013;33:1691-716.

16. Heaston DK, Putman CE, Rodan BA, Nicholson E, Ravin CE, Korobkin M, Chen JT, Seigler HF. Solitary pulmonary metastases in high-risk melanoma patients: A prospective comparison of conventional and computed tomography. AJR Am J Roentgenol. 1983;141:169-74.

17. Fishman EK, Kuhlman JE, Schuchter LM, Miller JA, Magid D. CT of malignant melanoma in the chest, abdomen, and musculoskeletal system. Radio Graphics. 1990;10:603-20.

18. Buzaid AC, Sandler AB, Mani S, Curtis AM, Poo WJ, Bolognia JL, Ariyan S. Role of computed tomography in the staging of primary melanoma. J Clin Oncol. 1993;11:638-43.

19. Jamil LH, Kashani A, Scimeca D, Ghabril M, Gross SA, Gill KR, Hasan MK, Woodward TA, Wallace MB, Raimondo M. Can endoscopic ultrasound distinguish between mediastinal benign lymph nodes and those involved by sarcoidosis, lymphoma, or metastasis? J Dig Dis Sci. 2014;59:2191-8.

20. Lens MB, Newton-Bishop JA. An association between cutaneous melanoma and non-Hodgkin's lymphoma: Pooled analysis of published data with a review. Ann Oncol. 2005;16:460-5.

21. Murali R, Doubrovsky A, Watson GF, McKenzie PR, Lee CS, McLeod DJ, Uren RF, Stretch JR, Saw RP, Thompson JF, Scolyer RA. Diagnosis of metastatic melanoma by fine-needle biopsy. Analysis of 2,204 cases. Am J Clin Pathol. 2007;127:385-97.

22. Morrison C, Young DC, Wakely PE Jr. Cytopathology of malignant melanoma in conventional and liquid-based smears. Am J Clin Pathol. 2002;118:435-441.

23. Lindsey KG, Ingram C, Bergeron J. Cytological diagnosis of metastatic malignant melanoma by fine-needle aspiration biopsy. Semin Diagn Pathol. 2016;33:198-203. 
24. Herth FJF, Eberhardt R, Vilmann P, Krasnik M, Ernst A. Realtime endobronchial ultrasound guided transbronchial needle aspiration for sampling mediastinal lymph nodes. Thorax. 2006;61:795-8.

25. Arkenau HT, Kefford R, Long GV. Targeting BRAF for patients with melanoma. Br J Cancer. 2011;104:392-8.

26. Deniger DC, Kwong MLM, Pasetto A, Dudley ME, Wunderlich JR, Langhan MM, Lee C-C R, Rosenberg SA. A pilot trial of the combination of vemurafenib with adoptive cell therapy in patients with metastatic melanoma. Clin Cancer Res. 2017; 23:351-62.

27. Chapman PB, Hauschild A, Robert C, Haanen JB, Ascierto P, Larkin J, Dummer R, Garbe C, Testori A, Maio M, Hogg D, Lorigan P, Lebbe C, Jouary T, Schadendorf D, Ribas A, O’Day SJ, Sosman JA, Kirkwood JM, Eggermont AM, Dreno B, Nolop K, Li J, Nelson B, Hou J, Lee RJ, Flaherty KT, McArthur GA; BRIM-3 Study Group. Improved survival with vemurafenib in melanoma with BRAF V600E mutation. N Engl J Med. 2011; 364:2507-16.
28. Asano F, Aoe M, Ohsaki Y, Okada Y, Sasada S, Sato S, Suzuki E, Semba H, Fukuoka K, Fujino S, Ohmori K. Complications associated with endobronchial ultrasound-guided transbronchial needle aspiration: A nationwide survey by the Japan Society for Respiratory Endoscopy. Respir Res. 2013;14:50.

29. Eapen GA, Shah AM, Lei X, Jimenez CA, Morice RC, Yarmus L, Filner J, Ray C, Michaud G, Greenhill SR, Sarkiss M, Casal R, Rice D, Ost DE; American College of Chest Physicians Quality Improvement Registry, Education, and Evaluation (AQuIRE) Participants. Complications, consequences, and practice patterns of endobronchial ultrasound-guided transbronchial needle aspiration. Results of the AQuIRE registry. Chest. 2013;143:104453. 